\title{
Studies of the Electron Transport Systems of Heart Muscle: Biochemical and Antigenic Properties of a Soluble DPNH Dehydrogenase ${ }^{1}$
}

\author{
BRUCE MACKLER, ${ }^{2}$ R. J. ERICKSON ${ }^{3}$ STARKEY D. DAVIS, T. D. MEHL, \\ CHARLES SHARP, ${ }^{3}$ RALPH J. WEDGWOOD, GRAHAM PALMER, ${ }^{2}$ \\ AND TSOO E. KING \\ Department of Pediatrics, University of Washington, Seattle, Washington; The Biophysics \\ Research Division, University of Michigan, Ann Arbor, Michigan; and Oregon State \\ University, Corvallis, Oregon \\ Received August 25, 1967
}

\begin{abstract}
Highly purified DPNH dehydrogenase has been prepared from preparations of DPNH oxidase. The enzyme has an average molecular weight of 80,000 and contains flavin, nonheme iron, and labile sulfide groups in an approximate ratio of $1: 2: 2$, respectively. In electron paramagnetic resonance studies the dehydrogenase showed a $g=1.93$ signal upon reduction with hydrosulfite, but not with DPNH, which suggests that the iron is not active in the enzymic catalysis. Studies of immunodiff usion and of enzyme inhibition with specific antibodies suggest that the DPNH dehydrogenase has not been grossly modified during preparation, and that it and the dehydrogenases prepared by the methods of King and Howard and Cremona and Kearney are related to each other and to preparations of DPNH oxidase.
\end{abstract}

Previously, several preparations of DPNH dehydrogenase have been isolated from heart muscle. The dehydrogenases fall into two general categories: the smaller soluble preparations described by Mahler et al. (1), DeBernard (2), King and Howard (3) and Mackler (4) (molecular weight 70,000$100,000)$; and the larger DPNH dehydrogenase complexes of Ringler et al. (5) (molecular weight about $1,000,000$ ), and Cremona and

${ }^{1}$ This work was supported in part by grant $\mathrm{H}$ 5457 from the National Institutes of Health; by Research Training Grant 5-T1-HD-5 from the National Institutes of Health; and grants from the Initiative 171 fund, University of Washington; the American Heart Association; and the Life Insurance Medical Research Fund.

2 Research Career Development Awardee of the National Institutes of Health, 2K 3-HD-1128 (B.M.) and GM-K3-31,213 (G.P.).

${ }^{3}$ Postdoctorate research trainee of the $\mathrm{Na}$ tional Institutes of Health; supported by Training Grant 5-T1-HD-5.
Kearney (6) (molecular weight about $550,000)$. The two types of dehydrogenases differ in other properties as well as molecular weight, the preparations of Cremona and Kearney containing much higher concentrations of nonheme iron and labile sulfide groups, and reacting at different rates with artificial acceptors than the preparations described by Mackeler and by King and Howard. Furthermore, the preparations of Ringler et al. and Cremona and Kearney can be further purified by a variety of treatments (7) yielding smaller, soluble dehydrogenases similar to those of the other investigators. Since the electron transport systems can be fragmented by different procedures to yield dehydrogenases of different characteristics, it is of interest to study the relationship of the soluble DPNH dehydrogenase prepared in our laboratory to the parent enzyme, DPNH oxidase, and to other dehydrogenases. This paper de- 
scribes the results of immunological and biochemical studies of the preparations which demonstrate a relationship between DPNH oxidase and the soluble DPNH dehydrogenase and suggest that the dehydrogenase is produced by fragmentation of DPNH oxidase without loss of essential properties.

\section{MATERIALS AND METHODS}

Beef heart DPNH oxidase (8), yeast electron transport particles (ETP) (9), and yeast DPNH dehydrogenase (10) were prepared as described previously. DPNH dehydrogenase was prepared from I)PNH oxidase as described by Mackler (4), but was further purified by final passage of the preparation thru a $30 \times 1.5-\mathrm{cm}$ column of Bio-Gel P-60 (obtained from the California Corporation for Biochemical Research). The DPNH dehydrogenases of King and Howard, and Cremona and Kearney were prepared as previously described $(3,6)$. Lipoyl dehydrogenase was prepared as described by Massey (11), with some modifications, up to the electrophoretically pure form.

Antisera against heart IPNH dehydrogenase and against DPNH oxidase were produced by intramuscular injection of the enzymes in Freund's adjuvant in rabbits. Serum was obtained in each case from the rabbits before injection of enzyme for use as a control. Partially purified antisera and control sera were prepared from the rabbit sera by addition of a saturated (at $0^{\circ}$ ) solution of ammonium sulfate, pH 7 , to $50 \%$ of the final volume. All procedures were performed at $0-4^{\circ}$. The suspension was allowed to stand with stirring for 10 minutes and was then centrifuged for 15 minutes at $40,000 \mathrm{rpm}$ in the No. 40 rotor of the spinco model L ultracentrifuge. The residue was taken up in a minimum of distilled water, dialyzed against $0.9 \% \mathrm{NaCl}$ for 18 hours, and stored at $-70^{\circ}$. The final product was demonstrated to contain a high concentration of gamma globulin by immunoelectrophoresis (12). Immunodiffusion studies (13) were done in 0.4\% agarose (Bausch and Lomb) in $\mathrm{pH} 7.2$ phosphate buffer. DPNH oxidase was suspended in $1 \%$ Tween for better resolution of precipitin lines.

Assays for enzymic activity were carried out at either $30^{\circ}$ or $38^{\circ}$ with 2,6 -dichlorophenolindophenol (indophenol), ferricyanide, cytochrome $c$, and oxygen as acceptors, as described previously $(4,9,12,14)$. For studies of antiserum inhibition of enzyme activity, enzyme, antiserum, and the appropriate assay buffer were preincubated in cuvettes at the reaction temperature for 5 minutes. DPNH and, where called for, cyanide and versene, were then added, and the reaction was started by addition of the appropriate electron acceptor. In studies of DPNH oxidase activity the reactions were begun by addition of DPNH. Control serum was substituted for antiserum in control experiments, and except as noted had no effect on the enzymic reactions. Sodium chloride, in amounts present in the preparations of antiserum, did not influence enzymic activities. Preincubation of the enzymes with antiserum for periods of 10 minutes or more did not produce a significant increase in inhibiton of enzymic activity by the antiserum.

Sources of chemicals were as follows: DPNH and cytochrome $c$ from Sigma Biochemical Company; 2,6-dichlorophenolindophenol from Eastman Chemical Co., sodium barbital from Mallinckrodt; and Freund's adjuvant from Difco Laboratories. Fleischmann's yeast, obtained as a gift from Standard Brands, Inc., was used for preparation of the enzymes from yeast. The flavin, nonheme iron, labile sulfide, and protein contents of the preparations were determined as described previously $(9,15)$.

Electron paramagnetic resonance (EPR) spectra were obtained with a Varian V-4500 $\mathrm{x}$ band EPR spectrometer equipped with a special accessory that permitted operation in the temperature range $17^{\circ}-76^{\circ} \mathrm{K}$ (Palmer and Sands, to be published). Full details are given in the legend to Fig. 2.

\section{RESULTS}

Properties and composition of DPNII dehydrogenase. Preparations of soluble DPNH dehydrogenase of the highest purity catalyzed the oxidation of 95,80 , and 6.3 $\mu$ moles of DPNH per minute per milligram of enzyme protein with ferricyanide, indophenol, and cytochrome $c$, respectively as electron acceptors. When such preparations were studied in the Spinco model E analytical ultracentrifuge ${ }^{4}$ by velocity sedimentation techniques, the protein moved as a single symmetrical peak as shown in Fig. 1, and was estimated to be over $95 \%$ homogenous by calculation of the relative area distribution. The enzyme was calculated to have an average molecular weight of approximately $80,000\left(s_{20, w} 4.8\right)$ in other studies in the ultracentrifuge performed by equilibrium techniques (16).

Preparations of enzyme contained flavin, nonheme iron, and labile sulfide groups in the amounts shown in Table I. Based upon

${ }^{4}$ We are indebted to Mr. Roger Wade, Department of Biochemistry, University of Washington, for carrying out the ultracentrifuge studies. 


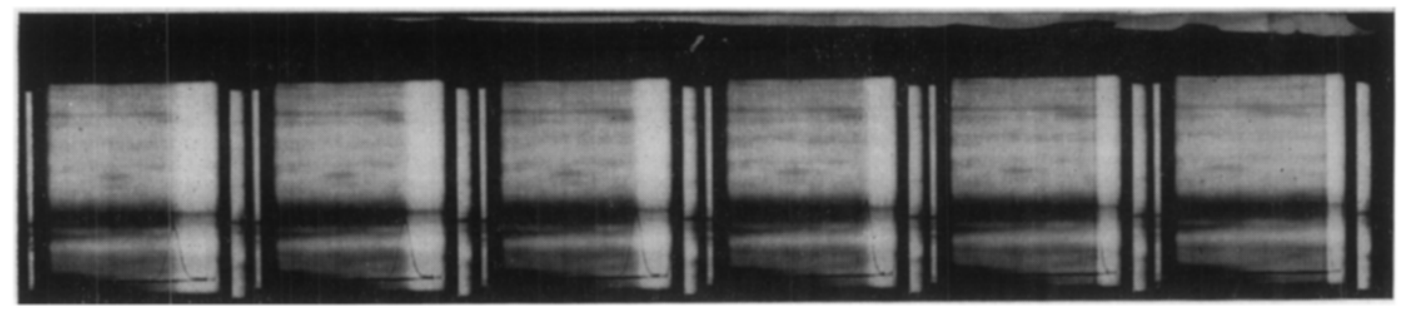

FIG. 1. Analytical ultracentrifuge pattern of velocity studies of DPNH dehydrogenase. Sedimentation is from right to left at $0,8,16,24,32$, and 40 minutes. $60,000 \mathrm{rpm} ; 8^{\circ} ; 3 \mathrm{mg}$ $\operatorname{protein} / \mathrm{ml}$.

TABLE I

Composition of IPNH Dehydrogenase

\begin{tabular}{cccc}
\hline Preparation & $\begin{array}{c}\text { Flavin (mole/ Iron (mole/mole } \\
\text { mole enzyme) }\end{array}$ & $\begin{array}{c}\text { I abile sulfide } \\
\text { enzyme) } \\
\text { (mile/mole } \\
\text { enzyme) }\end{array}$ \\
\hline 1 & 0.9 & 2.5 & 2.0 \\
2 & 0.7 & 2.9 & 1.8 \\
3 & 0.7 & 2.5 & 2.2 \\
4 & 0.9 & 2.3 & 1.2 \\
5 & 1.1 & 1.6 & 1.8 \\
Average & 0.9 & 2.4 & 1.8 \\
\hline
\end{tabular}

a molecular weight of 80,000 for the dehydrogenase (as determined from studies in the ultracentrifuge), the components are present in concentrations of $0.9,2.4$, and 1.8 moles of flavin, iron, and labile sulfide groups, respectively, per mole of enzyme. The flavin component has been identified previously $(17,18)$ as riboflavin (FMN). Other $5^{\prime}$-phosphate studies performed by EPR (see Methods) showed the presence of a prominent signal at $g=1.93$ upon reduction of the enzyme with dithionite (see Fig. 2). This is due to the nonheme iron component of the enzyme as described previously for other preparations by Beinert et al. (19) and Der Vartanian et al. (20). However, when the dehydrogenase preparations were reduced anerobically by addition of an excess of DPNH, only a small signal at $g=1.93$ was observed. This was approximately $5 \%$ of the magnitude of the signal found after addition of dithionite. The shape of the EPR spectrum deserves special comment. It is typical of a spin doublet in a rhombically distorted axial ligand field. This is indicated by the marked shoulder to the low-field side of the prominent high-field trough. Furthermore. the

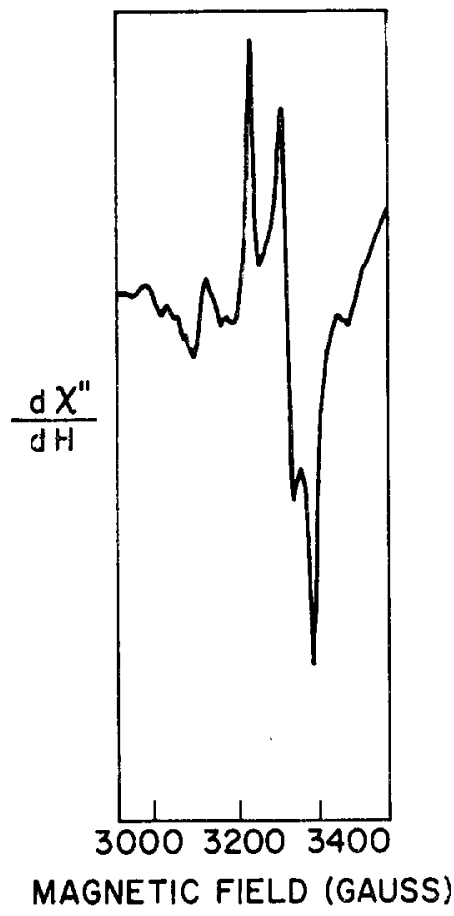

FIg. 2. Electron paramagnetic resonance spectrum of DPNH dehydrogenase $(4.4 \mathrm{mg} / \mathrm{ml})$ reduced with a few grains of solid dithionite. Spectrum was recorded at $58^{\circ} \mathrm{K}$ by using the following instrumental settings: microwave power, $15 \mathrm{~mW}$; modulation amplitude, 12 gauss; microwave frequency, $9.214 \mathrm{GHz}$; field scan rate, 400 gauss/ minute; time constant, 1 second.

$g$ value of the high-field trough was measured as 1.93. Both the shape of the spectrum and this $g$ value are similar to the EPR of reduced succinic dehydrogenase (21). However, flavin analyses show that the preparation does not contain any succinic dehydrogenase flavin (17). The two explanations for the nonheme iron EPR are therefore 
(a) either the DPNH dehydrogenase iron has become modified during purification so that very little is not reduced by DPNH and its EPR spectrum fortuitously resembles that observed with reduced succinic dehydrogenase, or $(b)$ the preparation contains the iron component of succinic dehydrogenase. We are unable to resolve these two alternatives at this time.

Immunologic tests of antisera and enzymes. Antisera prepared as described in Merhods against DPNH oxidase and DPNH dehydrogenase of heart muscle were studied by the double-diffusion method against both the heart DPNH dehydrogenase and DPNH oxidase. Two precipitin lines were formed in the immunodiffusion studies of the oxidase preparation with oxidase antiserum, and three precipitin lines formed in similar studies of the dehydrogenase with dehydrogenase antiserum, suggesting that the enzyme preparations were not homogeneous. In other studies two precipitin lincs were formed when each enzyme preparation was tested with heterologous antiserum, e.g., oxidase with dehydrogenase antiserum. With both antisera the precipitin lines fused with lines formed against the specific enzyme preparations, and suggested that the DPNH dehydrogenase and DPNH oxidase preparations share common antigens.

Immunodiffusion studies were also performed with other types of mitochondrial enzyme preparations. No precipitin lines were formed in studies of lipoyl dehydrogenase with either the oxidase or dehydrogenase antisera. The soluble DPNH dehydrogenase prepared as described by King and Howard (3) was also studicd by immunodiffusion, and no precipitin lines were found with the DPNH oxidase antiserum. However, one precipitin line was formed with the DPNH dehydrogenase antiserum which fused in a reaction of identity with one of the lines formed against our DPNH dehydrogenase preparation, suggesting that the two dehydrogenase preparations share a common antigen. In similar studies with the DPNH dehydrogenase complex prepared as described by Cremona and Kearney (6), two precipitin lines were formed with the DPNH oxidase antiserum and one precipitin line was formed

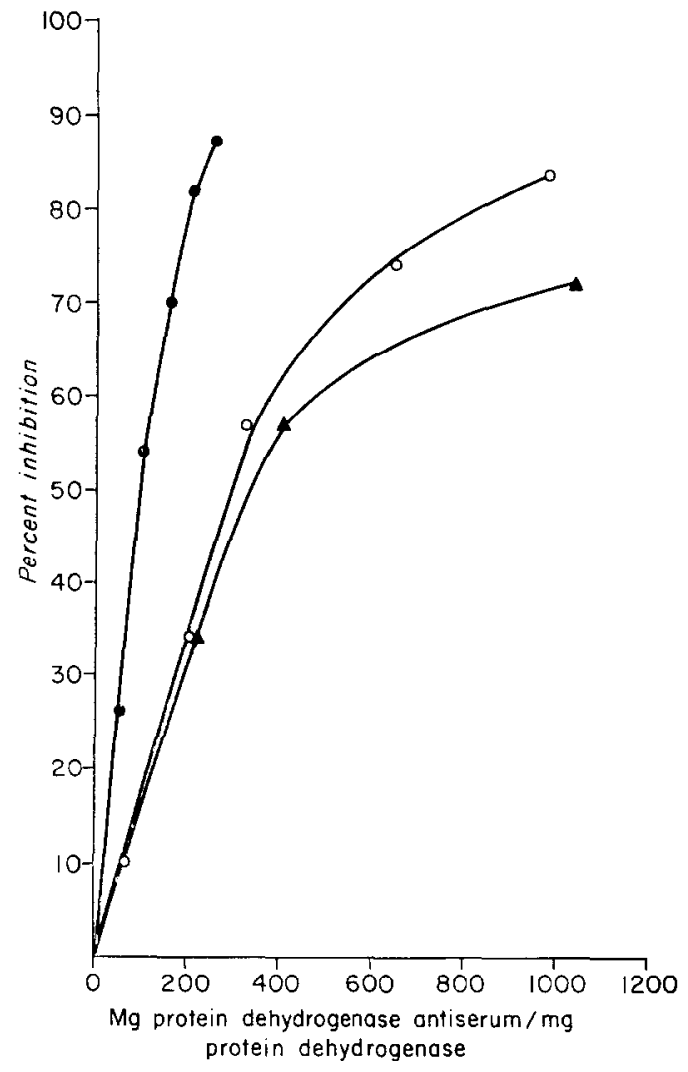

FIG. 3. Inhibition of various activities of DPNH dehydrogenase from heart muscle by an antiserum prepared against the dehydrogenase. Assays were performed at $30^{\circ}$ in a Gilford automatic spectrophotometer as described in METHods. -, Cytochrome $c ; 0$, indophenol; $\boldsymbol{\Delta}$, ferricyanide.

with the DPNH dehydrogenase anti-serum. Thus the DPNH dehydrogenase complex of Singer appears to share common antigens with both the DPNH oxidase and the DPNH dehydrogenase preparations. In other studies the antisera prepared against the DPNH oxidase and dehydrogenase preparations of heart muscle were tested against preparations of ETP (electron transport particles) and DPNH dehydrogenase from Saccharomyces cerevisiae, but no reaction could be demonstrated between the antisera and the yeast preparations by immunoelectrophoresis or by the method of Ouchtcrlony.

Effect of DPNH dehydrogenase antiserum on enzymic activity. As shown in Fig. 3, the DPNH dehydrogenase antiserum in- 
TABLE II

Effects of Purified Dehydrogenase Antiserum on Various Activities OF DPNH OXIDASE

\begin{tabular}{lcc}
\hline \multicolumn{1}{c}{ Activity $^{a}$} & $\begin{array}{c}S / E \\
(\mathrm{mg} / \mathrm{mg})^{b}\end{array}$ & $\begin{array}{c}\text { Inhibition } \\
(\%)\end{array}$ \\
\hline $\mathrm{DPNH} \rightarrow \mathrm{O}_{2}$ & 1800 & 0 \\
$\mathrm{DPNH} \rightarrow$ cyt. $c$ & 400 & 0 \\
$\mathrm{DPNH} \rightarrow \mathrm{Fe}(\mathrm{CN})_{6}^{3}-$ & 800 & 16 \\
& 1900 & 73 \\
\hline
\end{tabular}

${ }^{a}$ Assays were performed at $38^{\circ}$.

${ }^{b} \mathrm{Mg}$ of protein of antiserum/mg protein DPNH dehydrogenase.

TABLE III

InHibition of Various Activities of DPNH Oxidase by Purified DPNH Oxidase Antiserum

\begin{tabular}{lcc}
\hline \multicolumn{1}{c}{ Activity $^{a}$} & $\begin{array}{c}S / E \\
(\mathrm{mg} / \mathrm{mg})^{b}\end{array}$ & $\begin{array}{c}\text { Inhibition } \\
(\%)\end{array}$ \\
\hline $\mathrm{DPNH} \rightarrow \mathrm{O}_{2}$ & 1950 & 38 \\
$\mathrm{DPNII} \rightarrow$ cyt. $c$ & 370 & 50 \\
& 330 & 41 \\
DPNH $\rightarrow \mathrm{Fe}(\mathrm{CN})_{6}^{3-}$ & 900 & 16 \\
& 1800 & 73 \\
\hline
\end{tabular}

${ }^{a}$ Assays were performed at $38^{\circ}$.

${ }^{b} \mathrm{Mg}$ of antiserum protein $/ \mathrm{mg}$ of enzyme protein.

hibited all activities of the heart DPNH dehydrogenase but at different concentrations of antiserum; the reaction with cytochrome $c$ was more sensitive to inhibition than the reactions with indophenol or ferricyanidc. Fifty percent inhibition of enzymic activity was obtained with 96,310 , and 340 $\mathrm{mg}$ of antiserum per milligram enzyme when cy tochrome $c$, indophenol, and ferricyanide, respectively, were used as acceptors in the enzymic catalysis. On the other hand, the antiserum did not inhibit the activity of preparations of DPNH oxidase when oxygen and cytochrome $c$ were used as clcctron acceptors, but inhibited ferricyanide reductase activity at high levels of antiserum (Table II). However, only relatively low ratios of antiserum to DPNH oxidase could be used in the cytochrome $c$ reductase studies due to the large amounts of enzyme which are necessary for the assay procedure.
Studies were not performed with indophenol as acceptor, since this activity of DPNH oxidase was markedly inhibited by the partially purified control serum.

Effect of DPNH oxidase antiserum on enzymic activity. Table III shows the effects of the DPNH oxidase antiserum on the various activities catalyzed by DPNH oxidase. Although all activities of the enzyme were affected by the antiserum, the cytochrome $c$ reductase activity of the DPNH oxidase preparations was more sensitive to inhibition by the antiserum than were the DPNH oxidase or ferricyanide reductase activities. As mentioned earlier, inhibition of indophenol activity could not be studied because of the marked inhibition of activity by the control serum. The DPNH oxidase antiserum affected only the cytochrome $c$ reductase activity of the DPNH dehydrogenase, and produced 22 and $33 \%$ inhibition at levels of antiserum of 2000 and $4000 \mathrm{mg}$ of protein, respectively, per milligram of enzyme protein; this is a much higher ratio of antiserum to enzyme than was required for inhibition of activity of DPNH oxidase. The indophenol and ferricyanide reductase activities of the dehydrogenase were unaffected by the antiserum at levels of $2000 \mathrm{mg}$ of antiserum per milligram of enzyme.

In other studies the antisera prepared against the preparations of heart muscle DPNH oxidase and dehydrogenase were tested against preparations of ETP and DPNH dehydrogenase from $S$. cerevisiae, but no effects of the antisera could be demonstrated on any of the activities of either of the enzymes at levels of over $2000 \mathrm{mg}$ of antiserum protein per milligram of enzyme protein.

\section{DISCUSSION}

Preparations of DPNH dehydrogenase of the highest activity appear to be over $95 \%$ homogeneous in studies in the ultracentrifuge, and have an average molecular weight of approximately 80,000 , which is in good agreement with the minimal molecular weight calculated from the flavin content of the enzyme. The preparations contain 
nonheme iron and labile sulfide groups, and give a $g=1.93$ signal upon reduction in EPR studies, but it would appear that the iron and sulfide groups are not active in the enzymic catalysis since the signal is present only after reduction of the enzyme with hydrosulfite and not after reduction with DPNH. However, it has been shown in previous work that the reduction of flavin is catalytically significant in the enzyme $(17,22)$.

Although the preparations of DPNH dehydrogenase appeared homogeneous in studies in the ultracentrifuge, immunodiffusion studies of the enzyme indicate the presence of two minor components. The antibodies prepared against the DPNH dehydrogenase and DPNH oxidase appeared to be specific for the preparations since they did not react with similar preparations from yeast or with lipoyl dehydrogenase. In addition to interacting with their specific antigen, the antibodies crossreacted with the heterologous antigen (i.e., DPNH dehydrogenase antibody vs. DPNH oxidase, and DPNH oxidase antibody vs. DPNH dehydrogenase) in immunodiffusion studies and in studies of enzymic inhibition, and thus suggested that the DPNH dehydrogenase region of DPNH oxidase was not grossly modified by the solubilization procedures. Finally, the antibodies also crossreacted in immunodiffusion studies with the DPNH dehydrogenases prepared by the methods of King and Howard (3) and Cremona and Keamey (6), which suggests strongly that the three DPNH dehydrogenase preparations arc related to cach other, and are all derived from the same segment of the mitochondrial electron transport systems.

\section{ACKNOWLEDGMENTS}

The authors thank Standard Brands, Inc. for supplying the yeast for this study, and Mr. Byron Haynes and Mr. Robert Howard for their valuable technical assistance.

\section{REFERENCES}

1. Mahler, H. R., Sarpar, N. K., Vernon, L. P., and Alberty, R. A., J. Biol. Chem.199, 585 (1952).

2. DeBernard, B., Biochim. Biophys. Acta 23, 510 (1957).

3. King, T. E., and Howard, R. L., Biochim. Biophys Acta 37, 557 (1960).

4. Mackler, B., Biochim. Biophys. Acta 50, 141 (1961).

5. Ringler, R. L., Minakami, S., and Singer, T. P., Biochem. Biophys. Res. Commun. 3, 417 (1960).

6. Cremona, T., and Kearney, E. B., J. Biol. Chem. 239, 2328 (1964).

7. Witari, H., Kearney, E. B., and Singer, T. P., J, Biol. Chem. 238, 4063 (1963).

8. Mackler, B., in "Biochemical Preparations" (M. J. Coon, cd.), Vol. 9, pp. 40-43. Wiley, New York (1962).

9. Mackler, B., Coldipt, P. J., Duncan, H. M., Rao, N. A., and Huennekens, F. M., J. Biol. Chem. 237, 2968 (1962).

10. Duncan, H. M., and Mackler, B., Biochemistry 5, 45 (1960).

11. Massex, V., Biochim. Biophys. Acta 30, 205 (1958).

12. Crowle, A. J., "Immunodiffusion." Academic Press, New York (1961).

13. Ouchterlony, Ö., Progr. Allergy 6, 30 (1962).

14. Mackler, B., and Green, D. E., Biochim. Biophys. Acta 21, 1 (1956).

15. Duncan, H. M., and Mackler, B., J. Biol. Chem. 241, 1694 (1966).

16. Richards, E. G., and Schachman, H. K., $J$. Phys. Chem. 63, 1586 (1959).

17. Rio, N. A., Felton, S. P., Huennemens, F. M., ANd Mackler, B., J. Biol. Chem. 238, 449 (1963).

18. King, T. E., and Howard, R. L., J. Biol. Chem. 237, 1686 (1962).

19. Beinert, H., Heinen, W., and Palmer, G. Brookhaven Symp. Biol. 15, 229 (1962).

20. DerVartinian, D. V., Orme-Johnson, W. H., Hansen, R. E., and Beinert, H., Biochem. Biophys. Res. Commun. 26, 569 (1967).

21. Beinert, H., in "Non-Heme Iron Proteins: Role in Energy Conversion" (A. San Pietro, ed.), p. 29. Antioch Press, Yellow Springs, Ohio (1965).

22. M.cKLER, B., in "Flavins and Flavoproteins" (E. C. Slater, ed.), p. 427. Elsevier, Amsterdam (1966). 